\title{
Standing of Mortgage Rights on Cultivation Rights That Have Been Determined as Deflanded Land in Solok District
}

\author{
Alvin Rachman Putera; Yuslim; Hengki Andora \\ Master Program of Notary, Faculty of Law, Andalas University, Indonesia \\ http://dx.doi.org/10.18415/ijmmu.v8i5.2676
}

\begin{abstract}
Cultivation Right are rights to exploit land which is directly controlled by the state for agricultural, fishery or livestock companies for a period of time. One of the reasons for the removal of the cultivation right was because it was neglected. cultivation rights is one of the land rights that can be used as collateral for debt and encumbered with mortgage rights. The write-off of the mortgage rights because the write-off of land rights that are encumbered with a security right does not cause the guaranteed debt to be written off. In practice, the abolition of the cultivation right which is being subject to mortgage rights due to a decision to determine abandoned land creates confusion regarding the repayment of debts between the debtor (PT. Karatau Limo Sajati) and the creditor (PT. Bank Rakyat Indonesia Tbk.) And the difficulty of utilizing the former cultivation right object which is has been designated as abandoned land. The problems in this research are 1) how is the process of controlling cultivation right as an object of abandoned land in Solok Regency? 2) what is the position of the mortgage rights above the cutivation rights which has been designated as abandoned land in Solok Regency? 3) how is the utilization of the excultivation rights land on which a mortgage has been imposed after it has been designated as abandoned land in Solok Regency? The approach method used is juridical empirical, the nature of the research is descriptive analytical, the research data used is in the form of primary data, namely through interviews with sources and literature study to obtain secondary data. The data is processed systematically and analytically. The results showed that 1) the control process of PT. Karatau Limo Sajati as an abandoned land object which is carried out by means of inventory, identification and research, warnings, the proposal to determine abandoned land and the determination of abandoned land can actually be canceled through a lawsuit to the PTUN based on the weaknesses in the warning process. 2) the position of the mortgage over the cultivation rights which has been designated as abandoned land has been abolished, but the abolition of the mortgage because the termination of the land title does not cause the guaranteed debt to be canceled and subsequently the debtor's debt repayment is regulated in Articles 1131 and 1132 of the KUH Perdata. 3) The utilization of the ex-cultivation rights land on which a mortgage is imposed after it is designated as abandoned land is subject to a delay from BPN RI.
\end{abstract}

Keywords: Standing; Mortgage; Cultivation Rights; Abandoned Land 


\section{Background of Research}

Basic Agrarian Law Number 5 Year 1960 (UUPA) Article 27 explains the reasons for the abolition of land rights, including neglect. The state will act decisively to remove the management rights that have been granted if it is neglected. In article 29 paragraph (1), (2) and (3) Cultivation Right are given a maximum period of 25 years and for companies a maximum of 35 years and can be extended for a maximum period of 25 years. Article 34 letter e of the UUPA confirms that Cultivation Right are included in land rights that will be erased if abandoned. Observing the development of land rights, in its development, lands controlled in the form of property rights, cultivation rights and building use rights as well as usufructuary rights are not maximally utilized. In the sense that there is accumulation of land in a small group of people, because they have the capital to buy the widest possible land. However, the land is not used, the result is abandoned land. ${ }^{1}$ Etymologically, abandoned land consists of 2 (two) words, namely land and neglected. What is meant by land here is land in a juridical sense, namely the right to control the land. Abandoned words in the large Indonesian dictionary are not preserved, are not maintained, neglected and are not cared for. ${ }^{2}$ At this time, neglected land or abandoned land is regulated in Government Regulation number 11 of 2010 concerning control and utilization of abandoned land. Control of abandoned land is under the authority of the Head of the Regional Office of the Provincial Land Agency (Kanwil BPN) Article 4 paragraph (1). Government Regulation number 11 of 2010 does not provide the meaning of abandoned land, but rather regulates the object of control of abandoned land as mentioned in article 2, namely the object of control of abandoned land including land that has been granted rights to state land in the form of property rights

The right to cultivate, the right to use the building, the right to use and the right to manage, or the basis of control over land that is not cultivated, not used, or not used according to the circumstances, or the nature and purpose of granting rights or the basis for control. Article 3 of Government Regulation Number 11 of 2010 stipulates that the objects which are not included in the control of abandoned land are:

1 Freehold land or building use rights in the name of an individual that are accidentally not used in accordance with the circumstances or nature and purpose of granting the right.

2 Land that is controlled by the government, either directly or indirectly, and has the status or not the status of state or regional property which is not intentionally used according to the condition or nature and purpose of granting rights.

Apart from being stated in article 3 of Government Regulation Number 11 of 2010, land rights are not included in the object of control over abandoned land, namely, Building Use Rights over land management rights, Building Use Rights over Owned land, Right to Use over land freehold land. ${ }^{3}$ Article 8 explains that before the land is determined as the object of abandoned land, it will be carried out:

1 If based on the results of identification and research as referred to in article 7 paragraph (2) it is concluded that there is abandoned land, then the head of the Regional Office of BPN will notify and at the same time give the first written warning to the right holder, so that within 1 (one) month from the date of issuance of the warning letter, use the land according to the situation or according to the nature and purpose of granting the right or according to the permit / decision / letter as the basis for its authority,

2 If the right holder does not carry out the warning as referred to in paragraph (1), the Regional Office of BPN will give a second written warning with the same timeframe as the first warning.

\footnotetext{
${ }^{1}$ Supriadi, Agrarian Law, Sinar Grafika, Jakarta, 2018, p. 124.

${ }^{2}$ Urip Santoso, Housing Law, Kencana, Jakarta, 2014, p. 129.

${ }^{3}$ Ibid.
} 
3 If the right holder does not carry out the warning as referred to in paragraph (2), the Head of the Regional Office of BPN will give a third written warning with the same timeframe as the second warning.

4 If the land that is given a warning is bound by mortgage rights, it will also be notified to the holder of the mortgage.

Neglected land and abandoned land certainly have different meanings, indicated abandoned land is land that is allegedly not cultivated, not used, or not utilized in accordance with the circumstances or nature and purpose of granting rights or the basis for its control which has not been identified and researched, is regulated in Article 1 point 5 Regulation of the Head of the National Land Agency Number 4 of 2010 concerning Procedures for Controlling Abandoned Land. For land identified as neglected, a research will be conducted including verification of physical data and juridical data covering the type of land rights and location, as regulated in Article 8 paragraph (1) and (2). Article 3 letters a, b, c, and d describe the stages of control over abandoned land, namely, inventory of land rights or the basis for control over land that is indicated as neglected, Identification and research of abandoned lands, warnings to rights holders and designation of abandoned lands. Regulation of the Head of the National Land Agency of the Republic of Indonesia (PERKABAN) Number 4 of 2010 in Article 20 paragraph (1) letters $\mathrm{a}, \mathrm{b}$, and $\mathrm{c}$ regulates that the area of abandoned land is divided into three categories, namely, 100 percent of abandoned land, more than 25 percent up to less of the 100 percent neglected as described in paragraph (3) if part of the stretch is neglected, then the decision to determine the abandoned land will be applied to all of the land rights, and then to the former right holder is given back part of the land that was actually cultivated, used and utilized accordingly. with the decision to grant their rights, by going through the procedure for filing an application for land rights at the cost of the applicant in accordance with the provisions of laws and regulations and less than or equal to 25 percent is neglected. It is an obligation for all Indonesian citizens who already have land rights so as not to abandon land objects that have been given by the state to every legal subject. It becomes more effective if the legal subject who cannot manage land rights for various reasons, it is better to transfer management to another legal subject than the land being abandoned.

However, in practice, there are still legal subjects who deliberately neglect the object of land rights, as happened in Solok Regency, West Sumatra province against the Cultivation rights managed by PT. Karatau Limo Sajati which does not manage land objects and neglect land objects. In addition, cultivation rights managed by PT. Karatau Limo Sajati has been charged a mortgage on behalf of PT. Bank Rakyat Indonesia Tbk. Of course, the West Sumatra Provincial BPN Regional Office should use the authority that has been given by the state to control cultivation rights that have been identified as neglected in Solok Regency in order to safeguard national assets controlled by the state.

It becomes interesting if we examine in depth about the cultivation rights on which a mortgage burden in Solok Regency is indicated as neglected and has been designated as abandoned land by BPN RI. Based on the above background, the writer is interested to conduct research with the title "Standing of Mortgage Rights on Cultivation Rights That Have Been Determined as Deflanded Land in Solok District".

\section{Research Method}

In conducting this research, the author uses a juridical empirical approach which relies on primary data or results from field research and secondary data. The juridical approach, namely in making an approach, the principles and regulations that are still in effect are used in reviewing and seeing and analyzing the problems that are the object of research, starting from the analysis of the laws and regulations. 
While the definition of empirical approach is an approach arising from patterns of thinking in society and then obtained a truth which must be proven through real experiences in the community. This method is used by considering that the problems studied range in the legislation that is the relation of the regulations with other regulations with its application in practice.

\section{Result of Research}

Cultivation rights are one of the rights to land granted by the state which have a period of time to be used specifically for agriculture and plantations. According to Yanuardi, currently there are 7 (seven) Cultivation rights certificates in Solok Regency which are still managed by their respective rights holders, namely ${ }^{4}$ :

1. PT. Perkebunan dan perindustrian zanzibar covering an area of 320.92 hectares.

2. PT. Perkebunan alam permai sumbar nusa, covering an area of 390 hectares.

3. PT. Perkebunan nusantara enam covering an area of 141.33 hectares.

4. PT. Perkebunan nusantara enam covering an area of 178 hectares.

5. PT. Perkebunan nusantara enam covering an area of 64 hectares.

6. PT. Perkebunan nusantara enam covering an area of 285 hectares.

7. PT. Danau diatas makmur, covering an area of 285 hectares.

If added with the Cultivation rights of PT. Karatau Limo Sajati covering an area of 682 hectares which has been designated as abandoned land, then the total CULTIVATION RIGHTS in Solok Regency is 8 (eight) cultivation rights. Of the 8 (eight) CULTIVATION RIGHTS $\mathrm{s}$ that have been mentioned, the cultivation rights managed by PT. Danau Diatas Makmur, covering an area of 39.7 hectares, was indicated as being abandoned, but the cultivation rights has been re-managed by its right holders, the re-management of the object of land rights resulted in not continuing to the stage of determining abandoned land. ${ }^{5}$

From the overall cultivation rights management described above, it can be seen that not all rights holders who actually manage the cultivation rights physically properly are in accordance with the utilization that has been given, so that the cultivation rights is included in the category of land indicated as neglected or even designated as Neglected Land. PT. Karatau Limo Sajati is a limited liability company having its address at Senopati Street Number 114 Kebayoran Baru in Jakarta as the holder of the right to manage cultivation rights in Solok Regency with a Decree of Rights (SK) number 72 / Cultivation Rights / BPN / 1989 dated February 2, 1990, land certificate number 1 / Solok which is located in Labuah Saiyo Koto Gadang Guguk Village (formerly Bukit Gompong Village) Gunung Talang District, Solok Regency, West Sumatra Province covering an area of 682 hectares (Ha) and has been burdened with a mortgage (now called Mortgage Rights) Number 121/1994 dated 20 December 1994 on behalf of PT. Bank Rakyat Indonesia Tbk. (BRI) is domiciled at Jendral Sudirman Street Number 44-46, Central Jakarta.

Abandoned Land Control was originally regulated in Government Regulation Number 36 of 1998 concerning Control and Utilization of Abandoned Land which has been replaced by Government Regulation Number 11 of 2010 because land neglect has increasingly created social, economic, and welfare inequalities for the people and reduced environmental quality.

\footnotetext{
4. Yanuardi, Interview, Department of Land Law Relations, Solok Regency National Land Agency Office, Solok Regency, 14 September 2020.

${ }^{5}$ Nasrul, Interview, Land Infrastructure Section, Solok Regency National Land Agency Office, Solok Regency, 14 September 2020.
} 
Ordering abandoned land is closely related to the concept of social justice, because the concept of social justice must be translated as providing a basis for everyone to have equal rights and opportunities to receive a share of the benefits of land for themselves and their families so that they can get a decent life. ${ }^{6}$ Re-examining the objectives of the UUPA, namely rearranging dualistic agrarian regulations, in a unification of agrarian law that regulates the provision of prosperity to the people. What is in question is to examine the meaning of "for the greatest prosperity of the people" which is the basis of the UUPA. ${ }^{7}$

Control of abandoned land in West Sumatra often results in PTUN lawsuits from Land Rights Holders. The PTUN lawsuit was addressed to the Regional Office of the National Land Agency of West Sumatra Province. Determination of abandoned land often loses due to the enforcement procedures that are not in accordance with the prevailing regulations. The problems highlighted in the lawsuit regarding the procedures and processes for controlling abandoned land led to research conducted by the Regional Office of BPN in the field such as ${ }^{8}$ :

1. Neglected Land Identification Process.

2. Formation of Committee C.

3. Structuring Problems in Ordering.

4. First Warning Letter.

5. Second Warning Letter.

6. Third Warning Letter.

This is often the cause of the defeat of the BPN Regional Office in determining abandoned land, because if one of the conditions is not met, the land object cannot be designated as abandoned land and will be returned to the right holder.

The process of clearing abandoned land against land use rights that runs without a lawsuit from the right holders usually occurs in companies or legal entities that are no longer active. There are several reasons why companies or legal entities are not active in managing land use rights, namely ${ }^{9}$ :

1. Land use rights for business are not productive.

2. Often they get disturbances from the surrounding community in the form of control over Cultivation rightswhich makes it difficult for companies or legal entities to manage these Business Use Rights.

3. The lack of clarity in the process of releasing ulayat land to become land use rights has resulted in problems between indigenous peoples and companies or legal entities managing land use rights.

Committee $\mathrm{C}$ is the representative of the designated government agencies whose task is to carry out monitoring and evaluation of land objects. Prior to the formation of Committee $\mathrm{C}$ in the process of controlling the Cultivation rightsmanaged by PT. karatau Limo Sajati, land use rights for business still have the status of indicated abandoned land, so the Regional Office of BPN will carry out the process of identification, identification and research of the land use rights. After the BPN Regional Office conducts research on land use rights objects to the location, the head of the BPN Regional Office will form a Committee $\mathrm{C}$ to enforce control over the land use rights managed by PT. karor Limo Sajati. Committee C conducted a trial against the Right to Cultivate Business and from the results of the session Panita C

\footnotetext{
${ }^{6}$ Maria SW Sumardjono, Land Policy between Regulation and Implementation, Kompas, Jakarta, 2005, p. 15.

${ }^{7}$ Maria SW Sumardjono, Op.Cit. p. 10.

${ }^{8}$ Benny Sofyan, Interview, Head of the Land Control Section, Regional Office of the National Land Agency of West Sumatra Province, Padang, June 2, 2020.

${ }^{9}$ Benny Sofyan, Interview, Head of the Land Control Section, Regional Office of the National Land Agency of West Sumatra Province, Padang, June 2, 2020.
} 
recommended the Head of the BPN Regional Office to give a warning letter to PT. Karatau Limo Sajati as holders of Business Use Rights. ${ }^{10}$

Regulation of the Head of the National Land Agency of the Republic of Indonesia (Perkaban) Number 4 of 2010 is a rule to implement the provisions of Article 14 PP Number 11 of 2010 concerning Procedures for Controlling Abandoned Land which will be carried out in a series of processes, namely:

a. The inventory process. ${ }^{11}$

b. Identification and research. ${ }^{12}$

c. Warning letter. ${ }^{13}$

d. Proposal to designate abandoned land. ${ }^{14}$

e. Abandoned land designation. ${ }^{15}$

An inventory of land indicated as neglected is carried out by the Head of the Regional Office of the National Land Agency based on information obtained from direct field monitoring by the Regional Office of the National Land Agency, reports from the Land Agency and written reports from the public. ${ }^{16}$

Committee $\mathrm{C}$, which has been formed by the BPN Regional Office, will identify and research the target land objects indicated as neglected, including:

a. Verify physical data and juridical data.

b. Checking land books or notes and other documents to determine the presence of imposition, including data, plans, and stages of land use and utilization at the time of submission of rights.

c. Request information from right holders and other related parties, right holders and other parties must provide information or submit the required data.

d. Carry out a physical examination using existing technology.

e. Ploting the location of land use and utilization on a land map.

f. Make an analysis of the causes of abandoned land.

g. Prepare reports on the results of identification and research.

h. Conducting committee sessions to discuss and provide advice and considerations to the Head of the Regional Office in the context of disciplinary action.

i. Create and sign minutes.

The warning letter issued by the Regional Office of BPN and Committee C is carried out 3 (three) times with a period of 1 (one) month from the date the first warning letter is issued and in the case of land rights encumbered with Mortgage Rights, the warning letter is also notified to the holder of the Mortgage.

The Proposal for the Designation of Abandoned Land is one of the processes carried out after the third warning (last warning) based on the results of the evaluation and research of the West Sumatra Provincial BPN Regional Office and Committee C which has been formed by the Head of the Regional Office of the West Sumatra Province National Land Agency. The proposal for the determination of

\footnotetext{
${ }^{10}$ Benny Sofyan, Interview, Head of the Land Control Section, Regional Office of the National Land Agency of West Sumatra Province, Padang, June 2, 2020.

11 "Regulation of the Head of the National Land Agency of the Republic of Indonesia number 4 of 2010 concerning Procedures for Controlling Abandoned Land," Article 4.

12 "Regulation of the Head of the National Land Agency of the Republic of Indonesia number 4 of 2010 concerning Procedures for Controlling Abandoned Land," Article 7 paragraphs (3) and (4)

13 "Regulation of the Head of the National Land Agency of the Republic of Indonesia number 4 of 2010 concerning Procedures for Controlling Abandoned Land," Article 14.

14 "Regulation of the Head of the National Land Agency of the Republic of Indonesia number 4 of 2010 concerning Procedures for Controlling Abandoned Land," Article 8 paragraph (6).

15 "Regulation of the Head of the National Land Agency of the Republic of Indonesia number 4 of 2010 concerning Procedures for Controlling Abandoned Land," Article 19.

16 "Regulation of the Head of the National Land Agency of the Republic of Indonesia number 4 of 2010 concerning Procedures for Controlling Abandoned Land," Article 4.
} 
abandoned land as a final process before land rights are determined as abandoned land by the Head of the National Land Agency of the Republic of Indonesia. ${ }^{17}$

The Proposal for the Designation of Abandoned Land for Cultivation rights which is managed by PT. Karatau Limo Sajati was given the Regional Office of the National Land Agency of West Sumatra Province on 29 September 2011 Number 595 / 500.16 / IV / 2011 to the National Land Agency of the Republic of Indonesia Sisingamangaraja Street Number 2 Jakarta. The proposal letter explains that the third warning letter has been carried out against the Right to Cultivate which is managed by PT. Karatau Limo Sajati.

West Sumatra Provincial BPN Regional Office concluded that PT. Karatau Limo Sajati because the company is no longer active in managing Cultivation rights, is constrained by soil fertility and the involvement of the surrounding community in managing land use rights for businesses. ${ }^{18}$ The proposal for the establishment of Cultivation rightswhich is managed by PT. Karatau Limo Sajati as abandoned land is the basis for the Head of the National Land Agency of the Republic of Indonesia to determine abandoned land.

Determination of abandoned land carried out by the Head of the National Land Agency of the Republic of Indonesia based on a recommendation from the Head of the Regional Office of the Land Agency and the decision contains the abolition of land rights, termination of legal relations, and at the same time affirming that the land is directly controlled by the state. ${ }^{19}$

The West Sumatra Provincial BPN Regional Office and Committee C which have been formed by the BPN Regional Office have exercised their authority as a vertical agency of the Ministry of Agrarian and Spatial Planning or the National Land Agency in the Province which is under and responsible to the Minister of Agrarian and Spatial Planning or Head of the National Land Agency ${ }^{20}$ in carrying out the control up to determining the abandoned land of the former Cultivation Rights managed by PT. Karatau Limo Sajati who is being charged a mortgage.

Control of abandoned land to the determination of abandoned land against the Cultivation Rights managed by PT. Karatau Limo Sajati is in accordance with the process regulated in Government Regulation Number 11 of 2010 concerning Control and Utilization of Abandoned Land and Perkaban Number 4 of 2010 concerning Procedures for Controlling Abandoned Land. Therefore, according to the author, the Regional Office of BPN and BPN of Solok Regency, which are members of the Committee C, have worked according to their authority, which comes from PP No. 11/2010 and Perkaban No. 4/2010 to curb abandoned land and determine it. Because of the authority according to HD. Stoud is the authority of the institution that carries it out, first it must be determined in the Laws and Regulations, it can be in the form of Laws, Government Regulations, or lower level regulations.

If the former Cultivation Rights was managed by PT. Karatau Limo Sajati wants to be used by the Solok Regency Government according to the planning in the proposal, first it must confirm or notify the latest developments related to the mortgage rights on the former Cultivation Rights to BPN RI. Interpreting the contents of the letter, there are no problems related to the designation of abandoned land. However, the problem that BPN RI wants to know is regarding the mortgage rights of the former Cultivation Rights on behalf of PT. Karatau Limo Sajati which has no clarity.

\footnotetext{
${ }^{17}$ Benny Sofyan, Interview, Head of the Land Control Section, Regional Office of the National Land Agency of West Sumatra Province, Padang, June 2, 2020.

${ }^{18}$ Benny Sofyan, Interview, Head of the Land Control Section, Regional Office of the National Land Agency of West Sumatra Province, Padang, June 2, 2020.

19 "Regulation of the Head of the National Land Agency of the Republic of Indonesia Number 4 of 2010 concerning Procedures for Control of abandoned land," Article 19.

20 "Regulation of the Minister of Agrarian and Spatial Planning or the Head of the National Land Agency of the Republic of Indonesia Number 38 of 2016 concerning the Organization and Administration of the Regional Office of the National Land Agency and the Land Office," Article 1 paragraph (1).
} 
According to the author, in responding to this letter, the Solok Regency BPN must find out developments related to the mortgage rights of the former Cultivation Rights and send a delegation to PT. Central Bank Rakyat Indonesia Tbk, the information obtained from the BRI bank was then used to reply to the letter from BPN RI. Although the control of abandoned land has weaknesses in the process, the fact is that the determination of abandoned land to the Cultivation Rights of PT. Karatau Limo Sajati has not yet filed a lawsuit from the former rights holder. Therefore, the mortgage rights will not affect the determination of abandoned land and the Regional Government of Solok Regency can still manage the area of the land.

BPN RI does not have to delay the management of the former Cultivation Rights by considering the mortgage rights of the former Cultivation Rights. According to the author, this management is in accordance with Article 15 PP No. 11/2010 concerning Control and Utilization of Abandoned Land. Therefore, BPN RI can only delay or reject the management of abandoned land if it is not in accordance with the objectives of agrarian reform, the state's strategic program and other reserves. The postponement of management by BPN RI to the Solok Regency Government to manage the former Cultivation Rights object which has been designated as abandoned land by considering the Mortgage on the former Cultivation Rights is a wrong thing.

The delay in this case has made the determination of abandoned land find no legal certainty. In fact, the designation of abandoned land has absolutely no relationship to the debt that exists in the Mortgage. Although the Mortgage Rights in the Cultivation Rights have been removed.

\section{References}

\section{Books}

Maria SW Sumardjono,Land Policy between Regulation and Implementation,Kompas,Jakarta,2005,p. 15.

Supriadi, Agrarian Law, Sinar Grafika, Jakarta, 2018, p. 124.

Urip Santoso, Housing Law, Kencana, Jakarta, 2014, p. 129.

\section{Regulation}

Regulation of the Head of the National Land Agency of the Republic of Indonesia number 4 of 2010 concerning Procedures for Controlling Abandoned Land.

Regulation of the Minister of Agrarian and Spatial Planning or the Head of the National Land Agency of the Republic of Indonesia Number 38 of 2016 concerning the Organization and Administration of the Regional Office of the National Land Agency and the Land Office.

\section{Copyrights}

Copyright for this article is retained by the author(s), with first publication rights granted to the journal.

This is an open-access article distributed under the terms and conditions of the Creative Commons Attribution license (http://creativecommons.org/licenses/by/4.0/). 